\title{
Language Discourse in James Joyce's Short Stories The Grace and The Araby: A Cultural Studies
}

\section{Safoura Eskandari}

Student of Islamic Azad University, Tabriz., Iran

safora.eskandari62@gmail.com

\section{Abstract}

This study aims to investigate how the notion of language as cultural practices which construct social and cultural products function in James Joyce selected short stories, The Grace and The Araby within the framework of cultural materialism. Language is major concern of cultural studies and language is as the symbol of power. Language in literary texts plays a major role in constructing meaning and reflecting the author's intention. James Joyce could be placed among the most dominant cultural authors whose concern is the material life, social class, social identity and cultural crisis. As an outstanding author, Joyce is well known for his typical depiction, musical decoration as well as his sticking to proper cultural and social materials and issues such as religious matters. His selected short stories of Dubliners, revolve around the lifestyle of the Irish middle-class in Dublin around the late 1800s and early 1900s. James Joyce is not so much a writer as he is a painter of words. His works appear simplistic at first glance, but under analysis they reveal the inner world of a character and the reality of the common man through symbols, metaphors, and sensory analysis. Dublin is the city of silence which threads its way through the lives of the Dubliners, for this reason Joyce's characters are presented in a silent state. Such silence denotes the sterility of communication and the absence of the art of conversation. Most of Dubliners characters are portrayed as having the ability of verbal activity and they can speak, yet in most cases this ability fails them and they become tongue-tied.The only way which is left for them is speak in a whispering voice. In the modern age, life has completely changed and the city has become a modernized one. This latter is the epitome of such change that has a great effect upon the modern life, bringing with it the trauma and frustration of modern failure. Joyce's attempts to harness the effects of language and, increasingly with time, languages, may arguably be selected as the feature of his writing which mostly conditioned its technical transformations. Language is only one of those practices implicated in the symptoms of the crisis of late capitalist society. Faced with the ideological mystification of personal lives, Raymond Williams stressed the imperative of establishing connections by emphasizing the role of means of communication, he speaks of "productive communication in shaping community.

Keywords cultural materialism; language paralysis; hegemony; discourse

\section{Introduction}

This paper depicts Raymond William analysis of cultural materialism and power of language in James Joyce 's Dubliners within the framework of Cultural Materialism. Raymond Williams is one of the most important and influential cultural theorists. The core of 
this paper is to examine the language in the following short stories: Grace, Araby. Language plays a vital role in bringing out the theme throughout the story.

Raymond Henry Williams coined the term Cultural materialism. He was welsh academic, novelist and critic. He was an influential figure within the new left and in wider culture. His writings on publics, culture, the mass media and literature are a significant contribution to the Marxist critique of cultural and arts. (Williams, 1977) 'Empirical' work quite systematically transgressed the boundaries between elite and popular cultures. He was an interested in television and the press as a canonical literature and drama. Hence, his insistence that concepts both 'literature' and 'criticism' were forms of a class specialization and control of a general social practice, and of a class limitation of the question" (Williams, 1977). (Harris, 1927) pointed out that the cultural materialism is the strategy has found to be most effective in his effort to understand the causes of differences and similarities among societies and cultures. It is based on the simple premise that human social life is a response to the practical problems of earthly existence. Alan Sinfield, Cathering Belsey and Jonathan Dollimore are showing in their works the theory of Cultural Materialism. Their approach has been distinguished from the somewhat similar school of New Historicism in that they hold a less pessimistic view of the prospects of cultural dissidence and resistance to established powers. In view of the fact that literature performs an energetic role among the thought yet consolidation about power, a literary textual content does not in basic terms reveal the culture in which it is produced, however additionally actively contributes in conformity with the constitution of that culture. Cultural materialism tries according to convey in conformity with light how ideology then as a result existing social order tries in conformity with preserve itself through literature without losing its grip.

The Cultural materialist has some kind of idealistic motives, like as pure, unselfish devotion to humankind, rightly or wrongly, a large segment of world opinion. The Anthropological thinkers Marx has given right responsible for all the people. Likewise Joyce demonstrated in Dubliners, materialist as an elite people. They were ruling like a cruel and dominated to other. perception of the dominant culture is never the only one in the cultural field, although it is the most powerful, there are always residual and emergent strains within a culture that offer alternatives to hegemony. In other words, the dominant culture is always under pressure from alternative views and beliefs. The people dominating to other; they were losing all these ruling system one day. The people are not given response to them. It was happened in the global world. Now-a-days everyone has followed the government rules. Sometimes, it is changed occasionally. The materialist exploited some strategy and given right responsibility for all. Every part or group of people is called as a materialist.

\section{Review of Literature}

In Studying Societies and Cultures: Marvin Harris's Cultural Materialism and Its Legacy (2015), Lawrence A. Kuznar, Stephen K. Sanderson stimulate on the past, present and future of cultural materialism that is both laudatory of Harris' research strategy and critical of it." Paul Shankman, University of Colorado one of the most important anthropologists of all time, Marvin Harris was influential worldwide as the founder of cultural materialism. This book accessibly analyzes Harris's theories and their important legacies today. The chapters explore cultural materialism's epistemology and its relation to rational choice theory, Darwinian social science, and population pressures. The authors assess 
recent attempts to extend and reformulate cultural materialism and highlight cross-cultural, archaeological, and ethnographic applications of cultural materialism today.

In Re-imagining Cultural Studies: The Promise of Cultural Materialism (2002), Andrew $\mathrm{J}$ Milner traces the continuing influence on contemporary cultural studies of the kinds of cultural materialism developed by Raymond Williams and his successors. Williams now often appears in cultural studies as a vaguely remembered 'founding father', rather than a theorist whose work is still actively relevant to our present condition. Milner's book restores Williams to a central position in relation to the formation and development of cultural studies. It stresses the differences between Williams and that other founding father, Richard Hoggart, arguing that the label 'culturalism' cannot properly be applied to both. It argues that Williams stands in an essentially analogous relation to the British 'culturalist' tradition as do Foucault and Bourdieu to French structuralism and Habermas to German critical theory and that his cultural materialism is not so much culturalist as positively 'post-culturalist'. To those who have complained that contemporary cultural studies is insufficiently concerned with history, embeddedness and political economy, Milner suggests that this is so, in part, because Williams has become such a neglected resource.

In Cultural Materialism: On Raymond Williams (1995), Christopher Prendergast focuses and devotes his work on Raymond Williams. Widely regarded as one of the founding figures of international cultural studies, Raymond Williams is of seminal importance in rethinking the idea of culture. In tribute to his legacy, this edited volume is devoted to his theories of cultural materialism and is the most substantial and wide-ranging collection of essays on his work to be offered since his death in 1988.

In New Historicism and Cultural Materialism (1998), John Brannigan explains the development of new historicism and cultural materialism and demonstrates both their uses and weaknesses as critical practices. Exemplary readings of Conrad's Heart of Darkness, Gilman's The Yellow Wallpaper, the poetry of Alfred Lord Tennyson and Yeats' Easter 1916 serve to show and criticize the new historicist and cultural materialist interpretative strategies. Brannigan explores the potential future of the theories and the debates surrounding their controversial position in literary studies.

In "James Joyce's Usage of Diction in Representation of Irish Society in Dubliners: the Analysis of "The Sisters" and "The Dead" in Historical Context", Esmaeel Najar Daronkolaee argues the important role the diction plays in Dubliners, especially in the first and the last stories, "The Sisters" and "The Dead". The researcher attempts to show how phraseology helped Joyce to carry the themes of decrepitude, stagnation, and paralysis in Irish society at the turning of the twentieth century, and how this collection emphasizes the significance of societal context in understanding Joyce's texts, and vice versa. The hope of this decodification is to help readers having a clearer understanding of this collection of short stories, what happens beyond the text, and the commonalities prevailed in atmosphere of Dublin of 1900s. In order to fill in the concealed gaps in cryptic references of Joyce, etymological and symbolic functions of specific words, especially allusive ones, would be discussed in this article.

In "Local Belonging, Identities and Sense of Place in Contemporary Ireland", Tom Inglis studies what importance does identity with place have in the ongoing construction and redevelopment of personal and social identities? This paper follows on from recent research which suggests that in an increasingly geographically mobile and globalised societies like Ireland, a sense of place is still a strong marker of identity and central to people's knowledge and understanding of themselves and others. Combining findings quantitative findings from 
the International Social Survey Project with qualitative findings from a qualitative study of Contemporary Irish Identities, he shows that not only is identity with place of living still very strong, but that it is deep and complex and enmeshed with a sense of belonging to the place where people grew up, the wider county and the nation.

\section{Research Method}

The dominant cultural materialist is always under pressure, striving to substantiate their claim to superior explanatory power in situations where diverse features are resistant. William's argument that culture has always to be produced: 'social orders and cultural orders must be seen as being actively made: actively and continuously, or they may quite quickly break down' (William 1997, 201). (Howard, 1992) argues that the image of culture is the past resonates powerfully with 'some of the dominant elements of postmodern culture'. From this point of view, cultural materialism re-enacts new historicism's tendency to 'see an image of the seeing self' in its objects and representations. (Young, 1988) suggests that this structure of reflection is crucial to cultural materialism since it enables its proponents to argue the contemporary relevance of their historical findings. Communication is forbidden, and language has become the tool of the oppressor, as (Gussow, 1994) has proved that Joyce 's novel is about suppression of language and the loss of freedom of expression feel. Raymond Williams presents his own orientation to language thus:

we can also come to see that a sign-system is itself a specific structure of social relationships: "internally," in that the signs depend on, were formed in, relationships; "externally," in that the system depends on, is formed in, the institutions which activate it (and which are then at once cultural and social and economic institutions); integrally, in that a "sign-system," properly under stood, is at once a specific cultural technology and a specific form of practical consciousness: those apparently diverse elements which are in fact unified in the material social process. (Williams 1977, 140)

For Williams, the introduction of Gramsci's theory of hegemony and the role of intellectuals in cultural formations advanced and deepened the reach of cultural theory. Culture now becomes the site of power antagonisms and differential lines of force. It is at this junction that Williams resumes the actual genealogy of cultural studies from the debate over the "changing and contested structure of public education" and the influence of the new media (television, film) that has drastically revised "all received definitions of majority or popular cultural enterprise." The influence of Saussure, Freud, and others who valorized the text and the language-paradigm above all strikes Williams as dam aging in that it negated the paramount task of an all-sided cultural analysis, namely, "the identification of the matrix of any formation," "the analysis of specific relationships through which works are made and move." Cultural studies examine the socially and historically specifiable agency of the work's making, "an agency that has to include both content and intention, in relative degrees of determinacy, yet is only fully available as agency in both its internal (textual) and social and historical (in the full sense, formal) specificities" (Williams, 172).

Joyce explores the levels of the modern self, not giving the reader a clear identity to his characters. This results in the effect of the characters not possessing their own voice or language. This inability to express one's self has been discussed before in terms of Dubliners' characters and should be brought into this discussion as well. According to Trevor L. Williams in his article, "Resistance to Paralysis", there seems to be a "frequent tendency" in 
Dubliners for characters "not to be in control of language" and for these "characters simply to [not] possess a language" (438). Joyce allowed the devastating effects of colonialism in Ireland to seep through his gaps, which is indeed noticeable in the creative third space he invents in Dubliners. In all of the fifteen stories one finds these deafening silences and gaps, exposing the reader to the character's inability for progress and change from their current life situations for the better.

\section{Discussion}

\subsection{Language Paralysis in the Grace}

In the story Grace, During Joyce's lifetime, Catholicism was the religion fervently exercised by a majority in Ireland. Trevor L. Williams describes the characters as not being able to "define what Catholicism is" (448). Most fervent worshippers, however, had a vague idea of what it was meant to be Catholic. Trevor L Williams' argument that characters have trouble "controlling language" and who are in turn "controlled by the language they speak" (448). In the story, Irish culture mingles with the English language of the oppressor. There instances where the narrative reveals this. In the first instance, we find an allusion to England in the form of Protestant Mr Kernan. The friends who are trying to return him wholeheartedly to Catholicism can be read as a reference to Ireland, as the narrator describes in the following passage:

He was quite unconscious that he was the victim of a plot which his friends $\mathrm{Mr}$ Cunningham, Mr M'Coy and Mr Power had disclosed to Mrs Kernan in the parlour. The idea had been Mr Power's but its development was entrusted to Mr Cunningham. Mr Kernan came of Protestant stock and, though he had been converted to the Catholic faith at the time of his marriage, he had not been in the pale of the Church for twenty years [...] $\mathrm{Mr}$ Cunningham was the very man for such a case. (134)

This excerpt suggests the ever- present, religious battleground between Protestant England and Catholic Ireland. Mr Kernan having fallen to the bad ways of drinking needs to be "saved" by the Catholic Church, especially since he comes from a Protestant background. The confusion of the story's language reveals the artificiality of these distinctions between the cultural and religious sensibilities between the two countries. What the characters do not own is a language of social cohesion and solidarity, as they are divided along the lines of gender, religion, class, and ethnicity. In another instance of language power, we are presented to $\mathrm{Mr}$ M'Coy, the language authoritarian. He interrupts Mr Kernan's speech when either he cannot find the word he wants to use or when Mr M'Coy wishes to show dominance in the English language. In the following excerpt, we see a clear example of this:

- No, said Mr Kernan. I think I caught a cold on the car.

There's something keeps coming into my throat, phlegm or...

- Mucus, said Mr M'Coy.

- It keeps coming like from down my throat; sickening thing.

- Yes, yes, said Mr M'Coy, that's the thorax.

He looked at Mr Cunningham and Mr Power at the same time with an air of challenge. (136)

By using more advanced words, Mr M'Coy exposes the reader to Mr Kernan's "linguistic poverty" as coined by Trevor L. Williams (448). Since Mr Kernan does not understand the English language well, he cannot own it. Of course the Irish can use English as well as an Englishman can, however, Joyce wants the Irish reader to understand that 
English is not their own language and that they need to find their own in order to spur on Ireland's cultural growth.

In the last two examples, the theme is that of not owning the religious language. When the men who have come over to the Kernan's try and convince Mr Kernan of the validity of the Catholic Church, he is finally convinced because of two things: The respect he has for $\mathrm{Mr}$ Cunningham as being a learned man and because of his belief that the Jesuit order is an educated lot. This is revealed in the following dialogue:

- I haven't such a bad opinion of the Jesuits, he said [...] they're and educated order. I believe they mean well too. [...]

- They're all good men, said Mr Cunningham [...] The Irish priesthood is honored all the world over [...]

- Perhaps you're right, said Mr Kernan relenting [...] Mr Kernan [...] was impressed. He had a high opinion of Mr Cunningham as a judge of character and as a reader of faces. (141-42)

Another example of his inability to understand religion through language is given in the following excerpt where they discuss the scholarly greatness of Pope Leo:

- Pope Leo, you know, was a great scholar and a poet.

- He had a strong face, said Mr Kernan.

- Yes, said Mr Cunningham. He wrote Latin poetry. (144)

The process of identification here begins with Mr Kernan as an incurable drunk who is slowly but surely "saved" by the religious persuasions of his Catholic friends. Since he is ignorant in the teachings of the Catholic faith, he puts his trust in those who seem respectable or knowledgeable enough and ends up being persuaded blindly into accepting the Catholic faith over his Protestant one. His process of identification ultimately leads him into failure due to his own confusion about faith and language.

Another term worth discussing here is that of "culture" and its meaning in terms of literary studies. Seeing as that the term can be quite difficult to discern since it can circumscribe many others, a clear, detailed definition is in need. Stephen Greenblatt quotes the influential anthropologist Edward B. Tylor, who in his "Culture or Civilization" from 1871 wrote, "taken in its wide ethnographic sense, is that complex whole which includes knowledge, belief, art, morals, law, custom, and any other capabilities and habits acquired by man as a member of society" (225). In explaining "Local Culture", it would mean the "knowledge, belief, art, morals, law, custom" of Ireland and its people. In understanding Joyce's depiction of Ireland, we would need to understand the "influence" his country's "culture" had on what the idea of "home" was and how it emerges in Dubliners. His influences are well documented and indeed stem from his country's past and culture. Many have discussed the possibility of Irish history having had a strong impact on Joyce's construction of imaginary spaces in his writings. Basirizadeh in his article mentions that, "In de Beauvoir's view if women really want a status, they should deconstruct the structures of the masculine society and present their own definition of feminity. This definition would be the proof of woman's presence and existence counter-intuitive to masculine canon of knowledge in power" (2).

Joyce had concentrated on masking language as it appeared in pocket after pocket of his culture. By 1905, he had lived outside Ireland, and had probably found the "Irish" disease pandemic. It is understandable that he might mollify his judgment of individuals who use masking language, and shift his gaze inward in an attempt to discover why such use occurs. 


\subsection{Language Paralysis in the Araby}

The short story of "Araby" by James Joyce was published in 1914 in Dubliners which is a collection of fifteen short stories set in the Dublin city of Northern Ireland. "Araby" is one of those short stories in which traces of the colonization of Ireland by the Great Britain in the nineteenth century can be found. Since the context of the short story is set in Dublin, analyzing it in light of Cultural materialism theory has made it a special case. Language as one of the instances of nationality and culture, has a direct relationship to social changes and is in parallel with workings of power structures. The colonizer, overtly and covertly imposes its language on the colonized nation in order to extend its influence within the targeted culture. Therefore language can be regarded as the principal element in shaping postcolonial theory. Language of any nation has inseparable affinity with its culture and language is the verbal manifestation of a given culture. According to Paulin "The history of a language is often a story of possession and dispossession, territorial struggle and the establishment and imposition of a culture." (Paulin, 1983). Removing the mother tongue is one the most brutal tool used by the colonizing power for establishing their dominance. Irish language is a special case since it underwent major changes throughout its history. Irish language has always been attacked and the first one was during the twelfth century when the Anglo-Norman Knights came into Ireland.

This hybridity is evident in the case of "Araby". The infatuated narrator with imagining himself as a knight on a quest for bringing the Holy Grail, reaches the bazaar and on his course the reader can trace signs of disillusionments. This reaches its peak when the narrator hears the English quarrel among the women and the men which results in the final sentence which is at the same time the climax of the story and is where the epiphany occurs. Joyce indirectly criticizes the way (imposition of English language) the colonizer has made the "splendid" bazaar (Ireland) such a dull and depressing land. In "Araby", Joyce through a realistic and lucid style of writing shows how the domination of the British ruling has been so intertwined within the Irish culture and he also portrays the entrapment of Irish people by this domination from which there seems to be no way out. Joyce shows that although his language has been influenced by the colonization power of British Empire, still he is able to portray his critique of the ruling power and to portray the living status of Irish people through this language. As the most significant colonizing tool for colonizers, language has been turned against the workings of the colonizing power.

In Dubliners there are several examples of dominate women. However, it should be considered that since the Irish society at the time of the illustration of Dubliners by Joyce in general was a paralyzed society, the concept of dominant and dominating characters, find alternative meaning. For Joyce, language was the primary mode of apprehension of the real. This may seem obvious, but it is not true of all writers. Many writers are most concerned with social, political, or religious ideas, with events or psychological analysis. Such writers take language more or less at face value, and use it to express the truths they perceive about these things. Joyce, on the other hand, learned to perceive and perhaps even to feel through language, he depicts all of his young characters as doing so.

"Araby" forms the first phase of Dubliners that is childhood and "Araby"is the third and the last of this trio. Joyce's style is lucid, direct and realistic in Dubliners and in it he tries to mirror Dublin's atmosphere in a way that is dull, dreary, depressing and gloomy. The emergence of superior/inferior, Self/Other, as well as supranational concepts such as language and religion are in the story. 
The meaning of politics is nothing but hegemony and superiority of a group of people over other groups of people and this paradigm is performed in many different ways. This is a problem in which many countries and regimes have been involved. If this is extended to other issues and problems there would appear several implications. One of these implications would be the conflicts and contradictions between people and government and even between the structures of the government itself. As we read the story from the beginning, we are encountered with the atmosphere of Dublin as a dull and depressing place. This atmosphere is clearly visible from the beginning words of the story. Perhaps the climax of this dark atmosphere can be found it the third paragraph:

When the short days of winter came dusk fell before we had well eaten our dinners. When we met in the street the houses had grown sombre. The space of sky above us was the colour of ever-changing violet and towards it the lamps of the street lifted their feeble lanterns. The cold air stung us and we played till our bodies glowed. Our shouts echoed in the silent street. The career of our play brought us through the dark muddy lanes behind the houses, where we ran the gantlet of the rough tribes from the cottages, to the back doors of the dark dripping gardens where odours arose from the ashpits, to the dark odorous stables where a coachman smoothed and combed the horse or shook..... (Joyce 1)

Throughout the story, can easily notice this dark and depressing atmosphere. This atmosphere precedes the epiphany, which symbolize the sort of blindness the narrator experiences at the beginning of the story.

The first instance which is at the beginning of the story is their house which formerly was the house for a dead priest. The dead priest represents the deadening status of the dominant Roman Catholicism within Ireland. These contradictory images within the story strengthen the image of the domination and prevalence of British culture and government across Dublin: (the English accent of the woman in the bazaar, Roman Catholic Church and the deadened atmosphere of the house which belonged to a priest who is now dead). There are further images within the story which support this claim. The beginning words of the first paragraph (North Richmond Street, being blind...) reflect the boy's relationship to reality which is blind. Actually the real North Richmond Street was blind, however this has also symbolic significance within the story. He uses this blind (dead-end) street as a symbol for the boys who are playing within it as aimless activity. The playing boys themselves stand for the Irish people who are uselessly struggling in the wrong and dead-ended way. "An uninhabited house of two storeys stood at the blind end, detached from its neighbors in a square ground" (Joyce 1). The kind of house drawn here though is real, perhaps also represents the kind of life within Dublin which is going nowhere. The kind of house which is isolated represents their limitation and lack of freedom for growth and advance while being under the British rule. "I held a florin tightly in my hand as I strode down Buckingham Street towards the station" (Joyce 2). Florin was a silver coin that is now obsolete and worth two shillings. It had the picture of Queen Victoria on one side and for Irish people it was the reminiscent of the domination of the British rule. Also holding it tightly in his hand, the narrator implies the economic poverty imposed on them from the part of British rulers as a result of their domination.

As mentioned before, the narrator himself represents the dominated Ireland and Mangan's sister over whom he had no control, represents the British rule and domination over Ireland. We know the girl through the name of "Mangan's sister". Clarence Mangan was the name of a poet who was Joyce's favorite and also was a poet to whom W. B. Yeats and 
Lionel Johnson paid considerable attention. In his poetries there can be seen some poems on Irish nationalism. He calls the girl who, as mentioned before stands for the colonizer, as Mangan's sister. Perhaps to show that the British rule is so much prevalent that has presence within the very warp of not only Ireland but also within Irish people and culture.

According to almost all feminist scholar's patriarchy refers to rule of the father in a male dominated society as a social and ideological construct which regards men as superior to women. They are of opinion that men's domination over female sexuality is central to women's subordination. In fact, man is the head of the family who controls women's sexuality, labor, production, reproduction and mobility. Moreover, the effect of patriarchy can be traced in politics, public life and economy as well as in all aspects of social, personal, psychological and sexual existence.(Raoufzadeh,60)

Consequently, all Joyce's work is the notion that language and reality are one, that perfect truth was perfect language, that faulty language was somehow sinful. In "Araby", Joyce through a realistic and lucid style of writing shows how the domination of the British ruling has been so intertwined within the Irish culture and he also portrays the entrapment of Irish people by this domination from which there seems to be no way out. Joyce shows that although his language has been influenced by the colonization power of British Empire, still he is able to portray his critique of the ruling power and to portray the living status of Irish people through this language. Dubliners is a collection of short stories which portray the growth from childhood into adolescence (bildungsroman). "Araby" as the last of the first phase (childhood) begins with a "blind" narrator who after the "quest" in order to gain the Holy Grail in the splendid bazaar for his fair lady, undergoes an epiphany: the realization of the drabness of Dublin living under the domination of the British Empire.

\section{Conclusion}

In conclusion, the self-consciousness emerges as an awareness of both genre and linguistic expectations. Contrasting highly self-conscious, isolated literary men (or men with literary aspirations) with women who follow more romantic models, even stereotypes. In Dubliners, Joyce utilizes a clichéd story of doomed love ending in death-physical or spiritual. Language is influenced by a character's thought. To conclude the paper on selected short stories of Dubliners is a novel of Joyce that deals with cultural materialistic approach among Irish people. It lends itself to a Raymond Williams analysis of cultural materialism and symbol of power. The symbol of power meant that superior religion, politics. the concept of the language power is discussed in the selected stories of Dubliners What is created is an imaginary space where the migrant writer's conception of Ireland as a culturally divided space understood from the perspective of a migrant reveals itself through the language of the narrative. The Irishness of the characters emerges through this space, allowing the reader to follow their process of identification. What the characters demonstrate in their processes of identification is an inability to own their own language. This inability is presented either in the form of not owning their own voice, not owning the language of cultural distinction or of having social cohesion and solidarity. It is a story of Joyce's Ireland, portrayed in a light of total cultural desolation after years of colonial oppression. A portrayal of his native country, imaginatively constructed to awaken Ireland out of its cultural hibernation in the hopes of a new dawn of progressive cultural growth to form structures as a critical tool. Language is partly affected by a character's thought, as is often the case with Joyce's fiction. 


\section{References}

Abrams, M. H. (1993). A Glossary of Literary Terms. New York: Harcourt Brace Pub. Barker, Chris. (2004). Cultural Studies: Theory and Practice. London: Sage publication Inc.

Barler, Chris.(2003) Sage Dictionary of Cultural Studies. London: Sage Pub Inc.

Basirizadeh, Fatemeh. (2019). A Comparative Study of the Psychoanalytical Portrayal of the Women Characters by Virginia Woolf and Zoya Pirzad. Britain International of Humanatis and Social Sciences Journal, 1-8.

Bei, Xu. (2008) . On Reproducing Literary Style of Dubliners in Chinese, a Thesis, Shanghai International Studies University.

C. E. Bressler. (2007)Literary Criticism: An Introduction to Theory and Practice. The USA: PearsonPrentice Hall.

Claire, Kilroy. (2010) An Introduction to today's Irish Novelists. Dublin: Ireland Literature Exchange.

Daronkolahee, Esmaeel Najar.(2012) James Joyce's Usage of Diction in Representation of Irish Society in Dubliners: the Analysis of "The Sisters" and "The Dead" in Historical Context, The Journal of International Social Research Volume: 5 Issue: 23, PP. 169174.

Fargnoli, Nicholas A. and Gillespie, Michael P. (2006). Critical Companion to James Joyce: A Literary Reference to His Life andWork, Infobase Publishing, New York .

Freese, Lee and Burke, Peter J. (2009) Persons, Identities, and Social Interaction, Department of Sociology, Washington State University. Advances in Group Processes, Vol.11. Greenwich, Conn.: JAI Press.

Harris, Marvin. (2001) . Cultural Materialism: the Struggle for a Science of Culture, Walnut Creek, California: AltaMira Press. (https://www.google.com/search?q=Harris,+Marvin.+Cultural+Materialism)

Joyce, James. Dubliners: Authoritative Text, Contexts, Criticism. Ed. Margot Norris. New York: W.W. Norton, 2006.

M. J. Smith. (2000) Culture: Reinventing the Social Sciences. Philadelphia: Open University Press.

Raoufzadeh,N. Mohammadhosein,Sh. Zaheri Birgani, Sh. (2019) Analysis of Love, Death, Rebirth and Patriarchy in Two Contemporary Poetess Forough Farrokhzad and Sylvia Plath's Selected Poems. Budapest International Research and Critics Institute-Journal, 56-64.

Prendergast, Christopher. (1995). Cultural Materialism: On Raymond Williams, Volume 9. London, Minneapolis: University of Minnesota Press.

Roughley, Alan (1991.) James Joyce and Critical Theory: An Introduction. Ann Arbor: University of Michigan.

Williams, Trevor L.(2013). Resistance to Paralysis in Dubliners, MFS Modern Fiction Studies Project MUSE. Web. 05 Mar. 